\title{
Targeting mediators of Wnt signalling pathways by GnRH in gonadotropes
}

\author{
Samantha Gardner, Emmanouil Stavrou, Patricia E Rischitor, Elena Faccenda \\ and Adam J Pawson \\ Medical Research Council Human Reproductive Sciences Unit, The Queen's Medical Research Institute, 47 Little France Crescent, Edinburgh EH16 4TJ, Scotland, UK \\ (Correspondence should be addressed to A J Pawson; Email: a.pawson @ hrsu.mrc.ac.uk)
}

(S Gardner is now at Department of Biochemistry and Molecular Biology, Oregon Health and Sciences University, Portland, Oregon 97239-3098, USA)

\begin{abstract}
The binding of $\mathrm{GnRH}$ to its receptor on pituitary gonadotropes leads to the targeting of a diverse array of signalling mediators. These mediators drive multiple signal transduction pathways, which in turn regulate a variety of cellular processes, including the biosynthesis and secretion of the gonadotropins LH and FSH. Advances in our understanding of the mechanisms and signalling pathways that are recruited to regulate gonadotrope function are continually being made. This review will focus on the recent demonstration that key mediators of the canonical Wnt signalling pathway are targeted by $\mathrm{GnRH}$ in gonadotropes, and that these may play essential roles in regulating the expression of many of the key players in gonadotrope biology, including the $\mathrm{GnRH}$ receptor and the gonadotropins.
\end{abstract}

Journal of Molecular Endocrinology (2010) 44, 195-201

\section{Introduction}

GnRH occupancy of GnRH receptors leads to the activation of multiple signal transduction pathways (Naor 1997, 2009, Naor et al. 2000, Millar et al. 2004, 2008, Caunt et al. 2006, Dobkin-Bekman et al. 2006). In gonadotropes, GnRH activates phospholipase- $\mathrm{C} \beta$ via coupling to $G_{q / 11}$, resulting in the hydrolysis of membrane-bound phosphatidylinositol 4,5-bisphosphate into inositol 1,4,5-triphosphate and diacylglycerol, which respectively mobilise intracellular $\mathrm{Ca}^{2+}$ and activate protein kinase $\mathrm{C}$ (PKC). The diverse mechanisms and intracellular signalling pathways that have been reported to contribute to the regulation of gonadotrope function in response to GnRH stimulation have been reviewed extensively (Millar et al. 2004, 2008, Pawson \& McNeilly 2005, Naor 2009), and will not be discussed further here. Instead, this review will focus on the proposed roles of Wnt signalling mediators in regulating gonadotrope function in response to GnRH.

\section{A 'rough guide' to Wnt signalling}

Wnt signalling plays an important role in embryonic development influencing cell proliferation, survival and differentiation (Huelsken \& Behrens 2002, van Es et al. 2003, Moon et al. 2004, Nelson \& Nusse 2004). Aberrant Wnt signalling can lead to a range of diseases, most notably cancer (Polakis 2000). The canonical Wnt/ $\beta$-catenin pathway is perhaps the best described Wnt signalling pathway. The key effector of this pathway is $\beta$-catenin. In the absence of Wnt ligand (19 family members in humans) stimulation of the Frizzled (FZD) family of receptors (10 family members in humans), cellular $\beta$-catenin levels are kept very low. This is because $\beta$-catenin is held in a destruction complex, which includes amongst others adenomatous polyposis coli, axin, glycogen synthase kinase 3 (GSK3) and casein kinase 1 (CK1). GSK3 hyperphosphorylates $\beta$-catenin, thereby targeting it for ubiquitination and subsequent degradation via the proteasomal degradation pathway. When Wnts bind to and activate the FZD receptors, GSK3 activity is inhibited, allowing the levels of $\beta$-catenin to stabilise, and $\beta$-catenin translocates to the nucleus where it acts as a co-factor to $\mathrm{T}$ cell factor (TCF)/lymphoid enhancer factor transcription factors to promote the transcription of Wnt target genes, many of which are key in developmental processes (Huelsken \& Behrens 2002, van Es et al. 2003, Moon et al. 2004).

DOI: 10.1677/JME-09-0168 Online version via http://www.endocrinology-journals.org 
Less well characterised are the so-called non-canonical Wnt pathways, several of which have been proposed over the past 20 years, including the $\mathrm{Wnt} / \mathrm{Ca}^{2+}$ pathway and Wnt/c-Jun N-terminal kinase (JNK) pathway (Kuhl et al. 2000, van Es et al. 2003, Veeman et al. 2003, Kohn \& Moon 2005). These pathways are also activated by Wnt ligands binding to FZD receptors, and are thought to influence processes such as cell polarity, cytoskeletal reorganisation and cell movement, and utilise a diverse array of signalling mediators and transcription factors to drive these events, including $\mathrm{PKC}, \mathrm{Ca}^{2+} /$ calmodulin $(\mathrm{CaM})$, calcineurin $(\mathrm{CaN}), \mathrm{Ca}^{2+} / \mathrm{CaM}$-dependent kinase II, nuclear factor of activated $\mathrm{T}$ cells (NFAT), dishevelled, RhoA, Rac, Cdc42 and JNK (Kuhl et al. 2000, van Es et al. 2003, Veeman et al. 2003, Kohn \& Moon 2005, Katoh \& Katoh 2007).

Although there are two isoforms ( $\alpha$ and $\beta$ ) of GSK3, it is GSK3 $\beta$ that phosphorylates $\beta$-catenin, and targets it for ubiquitination and proteolytic degradation in the inactive canonical Wnt/ $\beta$-catenin signalling pathway (Frame \& Cohen 2001). Following activation of Wnt/ $\beta$-catenin signalling, GSK3 $\beta$ is inhibited by a poorly defined mechanism, thereby allowing the stabilisation and accumulation of $\beta$-catenin levels. GSK3 was originally identified as a key mediator of insulin signalling, and is now thought to be involved in many other signalling pathways with a diverse array of proposed substrates, including Tau, CREB, NFКB, MUC1, cyclin D1, MYC, NFAT and JUN (Frame \& Cohen 2001, Grimes \& Jope 2001). Multiple kinases have been implicated in the $\operatorname{Ser}^{9}$ and $\operatorname{Ser}^{21}$ phosphoinhibition of GSK3 $\beta$ and GSK3 $\alpha$ respectively, including the phosphatidylinositol 3-kinase (PI3K)-Akt/protein kinase $\mathrm{B}(\mathrm{PKB}$ ) signalling axis (such as that occurring in classical insulin signalling), p90RSK, PKC, protein kinase A (PKA), p70 S6 kinase and extracellular signal-regulated protein kinase (ERK) (Stambolic \& Woodgett 1994, Frame \& Cohen 2001, Grimes \& Jope 2001, Ding et al. 2005). It was initially thought that $\mathrm{Ser}^{9}$ GSK3 $\beta$ phospho-inhibition was the mechanism of GSK3 $\beta$ inhibition within the Wnt/ $\beta$-catenin pathway (Frame \& Cohen 2001). However, a study using a mouse knock-in of a Ser ${ }^{9}$ Ala GSK3 $\beta$ mutation reported normal embryonic development, suggesting that the $\operatorname{Ser}^{9}$ phospho-inhibition of GSK3 $\beta$ is not implicated in canonical Wnt signalling (McManus et al. 2005). Both isoforms of GSK3 are probably important for Wnt signalling because deletion of one has no effect, as long as the other is present, possibly suggesting isoform redundancy (Doble \& Woodgett 2003). Furthermore, in the mouse knock-in analysis where the $\mathrm{Ser}^{9 / 21}$ residues of GSK3 $\beta / \alpha$ respectively were mutated to alanine residues, normal $\beta$-catenin accumulation was observed in response to Wnt3a stimulation, again confirming that Ser $^{9}$ phosphorylation is not the mechanism for inhibiting GSK3 $\beta$ in Wnt/ $\beta$-catenin signalling (McManus et al. 2005). In addition, mutational studies of the 'insulin pool' of GSK3 suggest that insulin-induced Ser ${ }^{9 / 21}$ phospho-inhibition is not involved in the activation of the Wnt signalling pathway, and that Wnt signalling does not alter the glycogen synthase output of insulin signalling (Ding et al. 2000, $\mathrm{Ng}$ et al. 2009). The 'insulin' and Wnt pools of GSK3 $\beta$ may therefore be considered to be functionally distinct.

A number of theories have arisen regarding the mechanism involved in GSK3 $\beta$ inhibition in the Wnt/ $\beta$-catenin pathway. Some involve the GSK3 $\beta$ binding protein called frequently rearranged in advanced T-cell lymphoma (FRAT), which can block GSK3-induced phosphorylation of $\beta$-catenin without affecting glycogen synthase activity in the insulin signalling pathway (Thomas et al. 1999). Other theories involve the essential Wnt pathway protein dishevelled (Huelsken \& Behrens 2002, van Es et al. 2003, Moon et al. 2004). It has also been demonstrated that Wnt signalling inhibits GSK3 through a PKC-mediated mechanism (Cook et al. 1996), suggesting that PKC may have a role in inhibiting GSK3 within the canonical Wnt/ $\beta$-catenin pathway, in addition to the phosphoinhibition at $\operatorname{Ser}^{9 / 21}$ such as in classical insulin signalling. CK1 can enhance GSK3 activity by acting as a priming kinase. However, CK1 also has an essential role in positively transducing the canonical Wnt signal, suggesting its involvement in GSK3 $\beta$ inhibition (Doble \& Woodgett 2003). Alternatively, different CK1 isoforms may positively and negatively regulate GSK3 $\beta$ activity. Interestingly, GSK3 $\beta$ not only has been implicated in canonical Wnt/ $\beta$-catenin signalling, but may also play a negative regulatory role in the non-canonical Wnt $/ \mathrm{Ca}^{2+}$ pathway, in which it is thought to function as a nuclear export kinase, thus terminating NFAT transcriptional activity (Crabtree \& Olson 2002, van Es et al. 2003, Katoh \& Katoh 2007).

The FZD family of receptors are seven-transmembrane-spanning receptors that resemble $\mathrm{G}$ protein coupled receptor (GPCRs), and are now listed by the International Union of Pharmacology as a novel and separate family of GPCRs, the 'Class FZD' (Schulte \& Bryja 2007). One of the first demonstrations that FZDs signal via G-protein coupling came from the early studies by Malbon et al. (Liu et al. 1999, 2001). It was demonstrated that $\beta_{2}$-adrenergic receptor/FZD1 chimera bearing the cytoplasmic domains of rat FZD1 was able to stimulate $\beta$-catenin stabilisation and $\beta$-catenin/ TCF transcriptional activity in response to isoprenaline stimulation, and that this was inhibited when certain $\alpha$-protein $\alpha$-subunits $\left(\mathrm{G}_{\alpha_{\mathrm{o}}}\right.$ and $\left.\mathrm{G}_{\alpha \mathrm{q}}\right)$ were depleted by antisense RNA, or by pertussis toxin pretreatment (Liu et al. 1999, 2001). Importantly, these and subsequent studies appeared to suggest that non-FZD GPCRs could target $\beta$-catenin activity in response to stimulation by their cognate ligands (Malbon 2005). 


\section{Targeting Wnt signalling mediators by non-FZD GPCRs}

A number of non-FZD GPCRs have been shown to target $\beta$-catenin/TCF activity in response to their cognate ligands, including the prostanoid receptors (Fujino \& Regan 2001, Fujino et al. 2002), M1 muscarinic acetylcholine receptor (Farias et al. 2004), lysophosphatidic acid (LPA) receptor (Yang et al. 2005) and thromboxane $\mathrm{A} 2 / \mathrm{TP}_{\mathrm{a}}$ receptor (Yan \& Tai 2006). The first demonstration of non-FZD targeting of $\beta$-catenin/ TCF-dependent signalling was through the $\mathrm{FP}_{\mathrm{B}}$ prostanoid receptor (Fujino \& Regan 2001). Stimulation of $\mathrm{FP}_{\mathrm{B}}$-expressing cells with prostaglandin $\mathrm{F}_{2 \alpha}\left(\mathrm{PGF}_{2 \alpha}\right)$ led to reorganisation of $\beta$-catenin, a decrease in phosphorylation of cytoplasmic $\beta$-catenin and activation of $\beta$-catenin/TCF-dependent transcription. In addition to these findings, it was demonstrated that activation of the $\mathrm{EP}_{2}$ and $\mathrm{EP}_{4}$ prostanoid receptors by $\mathrm{PGE}_{2}$ promoted $\beta$-catenin/TCF-dependent transcription (Fujino et al. 2002). In addition, the $\mathrm{EP}_{2}$ and $\mathrm{EP}_{4}$ receptors were demonstrated to target $\operatorname{Ser}^{9}$ GSK3 $\beta$ phospho-inhibition by a PKA-dependent mechanism (Fujino et al. 2002). The M1 muscarinic acetylcholine receptor was demonstrated to inhibit GSK3 $\beta$ activity, stabilise $\beta$-catenin levels and induce the expression of the Wnt target genes $e n-1$ and $c y c D 1$ resulting in the protection of neurons from amyloid- $\beta$-peptide neurotoxicity in a rodent model of Alzheimer's disease (Farias et al. 2004). The LPA receptor was demonstrated to target $\beta$-catenin to induce colon cancer cell proliferation (Yang et al. 2005). LPA was shown to promote the nuclear translocation of $\beta$-catenin, activation of $\beta$-catenin/TCF-dependent transcription, phospho-inhibition of GSK3 $\beta$ and activation of $\beta$-catenin/TCF target genes. Furthermore, all these LPA-induced events were apparently dependent on conventional PKC activity (Yang et al. 2005). The thromboxane $\mathrm{A} 2 / \mathrm{TP}_{\mathrm{a}}$ receptor was demonstrated to activate $\beta$-catenin/TCF-dependent transcription apparently through the phospho-inhibition of GSK3 $\beta$ (Yan \& Tai 2006; Fig. 1).

\section{The GnRH receptor targets GSK3 $\beta$ phospho-inhibition and $\beta$-catenin/TCF transcriptional activity}

The above studies suggested that further cross-talk between signalling mediators of the Wnt/ $\beta$-catenin pathway and those activated by GPCRs is likely. Indeed, several recent studies have demonstrated that GnRH, acting at the GnRH receptor, can target mediators of the Wnt/ $\beta$-catenin signalling pathway in both a heterologous HEK293 model cell line and the LBT2 gonadotrope cell line (Gardner et al. 2007, Salisbury et al. 2007, 2008, 2009, Gardner \& Pawson 2009).

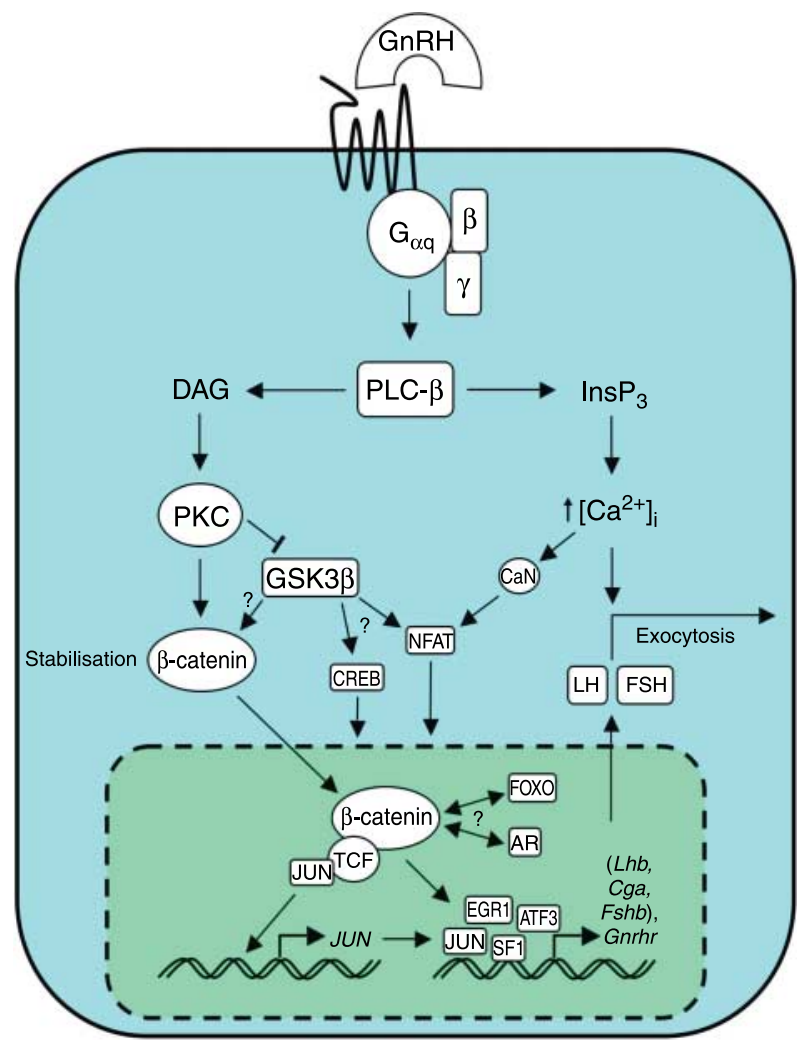

Figure 1 Targeting Wnt signalling mediators by $\mathrm{GnRH}$ in gonadotropes. GnRH activates PLC- $\beta$ via coupling to $G_{q / 11}$, resulting in the hydrolysis of membrane-bound phosphatidylinositol 4,5-bisphosphate into inositol 1,4,5-triphosphate (InsP $\left.\mathrm{P}_{3}\right)$ and diacylglycerol (DAG), which respectively mobilise intracellular $\mathrm{Ca}^{2+}$ and activate protein kinase $\mathrm{C}$ (PKC). GnRH targets $\mathrm{Ser}^{9}$ phospho-inhibition of GSK3 $\beta$ through a PKC-mediated mechanism, which may in part be responsible for the stabilisation and accumulation of $\beta$-catenin levels. $\beta$-catenin translocates to the nucleus where it acts as a co-factor to TCF, to increase the transcription of TCF target genes, including Fra1, Jun and Myc. $\beta$-catenin also interacts with SF1, which together with other DNA-binding proteins (including EGR1, JUN and ATF3) increases transcription of $L h b$, and possibly of Cga, Fshb and Gnrhr. In addition, $\beta$-catenin may act as a co-factor to regulate members of the FoxO family and the androgen receptor (AR). GSK3 $\beta$ may target the activities of other transcription factors in gonadotropes, including CREB and NFAT, which may therefore be subject to an additional level of regulation by $\mathrm{GnRH}$, since $\mathrm{GnRH}$ inhibits GSK3 $\beta$ activity. See text for details.

The initial studies reported GnRH-mediated nuclear accumulation of $\beta$-catenin, activation of $\beta$-catenin/TCFdependent transcription (using a TCF-dependent luciferase reporter plasmid) and the up-regulation of several $\beta$-catenin/TCF target genes including Jun, Fral and Myc (Gardner et al. 2007). In addition, it was demonstrated that GnRH targets Ser $^{9}$ GSK3 $\beta$ phospho-inhibition (Gardner et al. 2007). As discussed above, the accumulation of $\beta$-catenin in response to GnRH may be independent of the Ser ${ }^{9}$ phospho-inhibition of GSK3 $\beta$ since the Wnt pool of GSK3 $\beta$ is probably functionally 
distinct from the pool of GSK3 $\beta$ that GnRH targets. The mechanism whereby GnRH targets $\beta$-catenin accumulation and $\operatorname{Ser}^{9}$ GSK3 $\beta$ phospho-inhibition was shown to be mediated via $\mathrm{G}_{\mathrm{q} / 11}$ coupling, and is most likely PKC dependent (Gardner et al. 2007). Furthermore, GnRH does not signal through PI3K-Akt/PKB to target GSK3 $\beta$ phospho-inhibition, as is the case in classical insulin signalling, since pharmacological inhibition of PI3K failed to block $\beta$-catenin/TCF transcriptional activity in response to GnRH (Gardner et al. 2007).

Apart from its role as a TCF co-factor in the canonical Wnt signalling pathway, $\beta$-catenin can function as a co-factor to a number of other transcription factors relevant to gonadotrope biology, including SF1 and JUN (Angel et al. 1988, Desclozeaux et al. 2002, Shah et al. 2002, Gummow et al. 2003, Mizusaki et al. 2003, Parakh et al. 2006). Thus, the ability of GnRH to stimulate the expression of $\beta$-catenin/TCF target genes suggests that SF1- and JUN-responsive genes may also be targets of GnRH-dependent $\beta$-catenin/TCF transcriptional activity. This is because functional cross-talk between SF1, JUN and $\beta$-catenin/TCF signalling has been demonstrated in several studies (Shah et al. 2002, Gummow et al. 2003, Mizusaki et al. 2003, Veeman et al. 2003, Le Floch et al. 2005). Furthermore, $\beta$-catenin acts as a co-factor of SF1 through a direct interaction (Gummow et al. 2003, Mizusaki et al. 2003, Parakh et al. 2006), while JUN can interact co-operatively with TCF in the $\beta$-catenin/TCF complex at JUN promoter sites (Nateri et al. 2005).

\section{Targeting $\beta$-catenin/TCF transcriptional activity in gonadotropes}

The ability of GnRH to stimulate the expression of $\beta$-catenin/TCF target genes, and the finding that both SF1- and JUN-responsive genes may also be targets of GnRH-dependent $\beta$-catenin/TCF transcriptional activity, has important implications for gonadotrope function, including the expression of $L h b, C g a, F s h b$ and $G n r h r$ genes. An important study highlighting the role of $\beta$-catenin as a member of a transcription factor complex that drives maximal activity of the $L h b$ subunit promoter in response to GnRH was published (Salisbury et al. 2007). This study by Nilson et al. demonstrates the co-localisation of $\beta$-catenin with SF1 and EGR1 on the promoter of the $L h b$ subunit gene in response to GnRH, and suggests that endogenous SF1 and $\beta$-catenin can physically associate in L $\beta$ T2 cells (Salisbury et al. 2007). A role for GnRH targeting of $\beta$-catenin/TCF activity to regulate the expression of JUN-responsive genes including Cga, Fshb and Gnrhr, which additionally require SF 1 , is yet to be demonstrated. What is clear though is that $\beta$-catenin has an important role to play, and that it regulates gonadotrope responsiveness to GnRH.

\section{Concluding remarks and future direction}

The ability of GnRH to impinge on the activity of Wnt signalling mediators has several implications for further understanding key processes in gonadotrope biology. For example, CREB has a well-known role in regulating Gnrhr expression by targeting CRE sites within the Gnrhr promoter in response to GnRH stimulation (Cheng \& Leung 2001, Maya-Nunez \& Conn 2001). GSK3 has been proposed as one of a number of kinases that regulate CREB activity (Frame \& Cohen 2001, Grimes \& Jope 2001, Doble \& Woodgett 2003). Thus, by promoting the $\operatorname{Ser}^{9}$ phospho-inhibition of GSK3 $\beta$, GnRH signal transduction may provide an additional level of complexity in the regulation of CREB activity and its ability to function optimally at the Gnrhr promoter. GSK3 can also target the activity of the $\mathrm{Ca}^{2+}$-sensitive transcription factor NFAT by functioning as a nuclear export kinase, thereby terminating NFAT transcriptional activity (Crabtree \& Olson 2002). GnRH has been shown to mediate the derepression of the Fshb gene in the $\alpha \mathrm{T} 3-1$ gonadotrope cell line through the activation of the $\mathrm{Ca}^{2+} / \mathrm{CaN}$ pathway leading to NFAT-driven expression of Nur77 (Lim et al. 2007). Furthermore, a recent study has reported that GnRH-mediated $\mathrm{Ca}^{2+}$ /NFAT signalling does not act as the GnRH pulse frequency decoder in L $\beta$ T2 cells (Armstrong et al. 2009). It will be interesting to determine if there is a role for GnRH-mediated Ser ${ }^{9}$ phospho-inhibition of GSK3 $\beta$ in regulating NFAT nuclear residency and how this impacts on gonadotrope function with regard to these studies. As a multifunctional kinase with a diverse array of proposed targets, it is likely that many more roles for GSK3 in the gonadotropes will emerge.

Additional roles for $\beta$-catenin are also likely, including the regulation of androgen receptor (AR) activity. As an AR co-factor, $\beta$-catenin functions to both inhibit and stimulate AR target gene expression in a variety of cell types and tissues (Chesire \& Isaacs 2003, Mulholland et al. 2005, Terry et al. 2006, Robinson et al. 2008). Expression of Cga ( $\alpha$-polypeptide glycoprotein hormones), $L h b$ and Fshb subunit gene is widely reported to involve a component of androgen regulation in gonadotropes; however, possible roles for $\beta$-catenin in modulating AR activity at this level (in response to $\mathrm{GnRH}$ ) have not been reported yet (Curtin et al. 2001, Jorgensen \& Nilson 2001a,b, Curtin et al. 2004, Spady et al. 2004, Thackray et al. 2006, Burger et al. 2007, Thackray \& Mellon 2008). Furthermore, roles for FOXO transcription factors, which employ $\beta$-catenin as a co-factor, have been proposed (Essers et al. 2005, Malbon 2005, Hoogeboom et al. 2008, Jin et al. 2008, Hoogeboom \& Burgering 2009, Stavrou et al. 2009). Although clearly speculative, elucidating potential roles for GSK3 $\beta$ and $\beta$-catenin would 
enhance our understanding of the complexity of the regulation of gonadotropin subunit expression and gonadotrope function.

In conclusion, this review has highlighted both published and putative roles for mediators of the Wnt signalling pathways in targeting important biological processes in gonadotrope biology. We suggest that new avenues of research will continue to emerge in order to advance our understanding of the targeting of Wnt signalling mediators by GnRH to in turn regulate gonadotrope function. Indeed, such studies are already well underway.

\section{Declaration of interest}

The authors declare that there is no conflict of interest that could be perceived as prejudicing the impartiality of the research reported.

\section{Funding}

Research conducted in the authors' laboratory is funded by the Medical Research Council.

\section{References}

Angel P, Hattori K, Smeal T \& Karin M 1988 The jun proto-oncogene is positively autoregulated by its product, Jun/AP-1. Cell 55 875-885.

Armstrong SP, Caunt CJ, Fowkes RC, Tsaneva-Atanasova K \& McArdle CA 2009 Pulsatile and sustained gonadotropin-releasing hormone $(\mathrm{GnRH})$ receptor signaling: does the $\mathrm{Ca}^{2+} / \mathrm{NFAT}$ signaling pathway decode GnRH pulse frequency? Journal of Biological Chemistry 284 35746-35757.

Burger LL, Haisenleder DJ, Wotton GM, Aylor KW, Dalkin AC \& Marshall JC 2007 The regulation of FSH $\beta$ transcription by gonadal steroids: testosterone and estradiol modulation of the activin intracellular signaling pathway. American Journal of Physiology. Endocrinology and Metabolism 293 E277-E285.

Caunt CJ, Finch AR, Sedgley KR \& McArdle CA 2006 GnRH receptor signalling to ERK: kinetics and compartmentalization. Trends in Endocrinology and Metabolism 17 308-313.

Cheng KW \& Leung PC 2001 Human gonadotropin-releasing hormone receptor gene transcription: up-regulation by $3^{\prime}, 5^{\prime}$-cyclic adenosine monophosphate/protein kinase A pathway. Molecular and Cellular Endocrinology 181 15-26.

Chesire DR \& Isaacs WB $2003 \beta$-Catenin signaling in prostate cancer: an early perspective. Endocrine-Related Cancer 10 537-560.

Cook D, Fry MJ, Hughes K, Sumathipala R, Woodgett JR \& Dale TC 1996 Wingless inactivates glycogen synthase kinase-3 via an intracellular signalling pathway which involves a protein kinase C. EMBO Journal 15 4526-4536.

Crabtree GR \& Olson EN 2002 NFAT signaling: choreographing the social lives of cells. Cell 109 S67-S79.

Curtin D, Jenkins S, Farmer N, Anderson AC, Haisenleder DJ, Rissman E, Wilson EM \& Shupnik MA 2001 Androgen suppression of GnRH-stimulated rat LH $\beta$ gene transcription occurs through Sp1 sites in the distal GnRH-responsive promoter region. Molecular Endocrinology 15 1906-1917.

Curtin D, Ferris HA, Hakli M, Gibson M, Janne OA, Palvimo JJ \& Shupnik MA 2004 Small nuclear RING finger protein stimulates the rat luteinizing hormone- $\beta$ promoter by interacting with $\mathrm{Spl}$ and steroidogenic factor-1 and protects from androgen suppression. Molecular Endocrinology 18 1263-1276.

Desclozeaux M, Krylova IN, Horn F, Fletterick RJ \& Ingraham HA 2002 Phosphorylation and intramolecular stabilization of the ligand binding domain in the nuclear receptor steroidogenic factor 1 . Molecular and Cellular Biology 22 7193-7203.

Ding VW, Chen RH \& McCormick F 2000 Differential regulation of glycogen synthase kinase $3 \beta$ by insulin and Wnt signaling. Journal of Biological Chemistry 275 32475-32481.

Ding Q, Xia W, Liu JC, Yang JY, Lee DF, Xia J, Bartholomeusz G, Li Y, Pan Y, Li Z et al. 2005 Erk associates with and primes GSK-3 $\beta$ for its inactivation resulting in upregulation of $\beta$-catenin. Molecules and Cells 19 159-170.

Dobkin-Bekman M, Naidich M, Pawson AJ, Millar RP, Seger R \& Naor Z 2006 Activation of mitogen-activated protein kinase (MAPK) by GnRH is cell-context dependent. Molecular and Cellular Endocrinology 252 184-190.

Doble BW \& Woodgett JR 2003 GSK-3: tricks of the trade for a multitasking kinase. Journal of Cell Science 116 1175-1186.

van Es JH, Barker N \& Clevers H 2003 You Wnt some, you lose some: oncogenes in the Wnt signaling pathway. Current Opinion in Genetics and Development 13 28-33.

Essers MA, de Vries-Smits LM, Barker N, Polderman PE, Burgering BM \& Korswagen HC 2005 Functional interaction between $\beta$-catenin and FOXO in oxidative stress signaling. Science 308 1181-1184.

Farias GG, Godoy JA, Hernandez F, Avila J, Fisher A \& Inestrosa NC 2004 M1 muscarinic receptor activation protects neurons from $\beta$-amyloid toxicity. A role for Wnt signaling pathway. Neurobiology of Disease 17 337-348.

Frame S \& Cohen P 2001 GSK3 takes centre stage more than 20 years after its discovery. Biochemical Journal 359 1-16.

Fujino H \& Regan JW 2001 FP prostanoid receptor activation of a T-cell factor/ $\beta$-catenin signaling pathway. Journal of Biological Chemistry 276 12489-12492.

Fujino H, West KA \& Regan JW 2002 Phosphorylation of glycogen synthase kinase-3 and stimulation of T-cell factor signaling following activation of EP2 and EP4 prostanoid receptors by prostaglandin $\mathrm{E}_{2}$. Journal of Biological Chemistry 277 2614-2619.

Gardner S \& Pawson AJ 2009 Emerging targets of the GnRH receptor: novel interactions with Wnt signalling mediators. Neuroendocrinology 89 241-251.

Gardner S, Maudsley S, Millar RP \& Pawson AJ 2007 Nuclear stabilization of $\beta$-catenin and inactivation of glycogen synthase kinase-3 $\beta$ by gonadotropin-releasing hormone: targeting Wnt signaling in the pituitary gonadotrope. Molecular Endocrinology 21 3028-3038.

Grimes CA \& Jope RS 2001 The multifaceted roles of glycogen synthase kinase $3 \beta$ in cellular signaling. Progress in Neurobiology 65 391-426.

Gummow BM, Winnay JN \& Hammer GD 2003 Convergence of Wnt signaling and steroidogenic factor-1 (SF-1) on transcription of the rat inhibin alpha gene. Journal of Biological Chemistry 278 26572-26579.

Hoogeboom D \& Burgering BM 2009 Should I stay or should I go: $\beta$-catenin decides under stress. Biochimica et Biophysica Acta 1796 $63-74$.

Hoogeboom D, Essers MA, Polderman PE, Voets E, Smits LM \& Burgering BM 2008 Interaction of FOXO with $\beta$-catenin inhibits $\beta$-catenin/T cell factor activity. Journal of Biological Chemistry 283 9224-9230.

Huelsken J \& Behrens J 2002 The Wnt signalling pathway. Journal of Cell Science 115 3977-3978.

Jin T, George Fantus I \& Sun J 2008 Wnt and beyond Wnt: multiple mechanisms control the transcriptional property of $\beta$-catenin. Cellular Signalling 20 1697-1704. 
Jorgensen JS \& Nilson JH $2001 a$ AR suppresses transcription of the alpha glycoprotein hormone subunit gene through proteinprotein interactions with cJun and activation transcription factor 2. Molecular Endocrinology 15 1496-1504.

Jorgensen JS \& Nilson JH 2001b AR suppresses transcription of the LH $\beta$ subunit by interacting with steroidogenic factor-1. Molecular Endocrinology 15 1505-1516.

Katoh M \& Katoh M 2007 WNT signaling pathway and stem cell signaling network. Clinical Cancer Research 13 4042-4045.

Kohn AD \& Moon RT 2005 Wnt and calcium signaling: $\beta$-cateninindependent pathways. Cell Calcium 38 439-446.

Kuhl M, Sheldahl LC, Park M, Miller JR \& Moon RT 2000 The $\mathrm{Wnt} / \mathrm{Ca}^{2+}$ pathway: a new vertebrate Wnt signaling pathway takes shape. Trends in Genetics 16 279-283.

Le Floch N, Rivat C, De Wever O, Bruyneel E, Mareel M, Dale T \& Gespach C 2005 The proinvasive activity of Wnt-2 is mediated through a noncanonical Wnt pathway coupled to GSK-3 $\beta$ and c-Jun/AP-1 signaling. FASEB Journal 19 144-146.

Lim S, Luo M, Koh M, Yang M, bin Abdul Kadir MN, Tan JH, Ye Z, Wang W \& Melamed P 2007 Distinct mechanisms involving diverse histone deacetylases repress expression of the two gonadotropin $\beta$-subunit genes in immature gonadotropes, and their actions are overcome by gonadotropin-releasing hormone. Molecular and Cellular Biology 27 4105-4120.

Liu X, Liu T, Slusarski DC, Yang-Snyder J, Malbon CC, Moon RT \& Wang H 1999 Activation of a frizzled-2/ $\beta$-adrenergic receptor chimera promotes Wnt signaling and differentiation of mouse F9 teratocarcinoma cells via Galphao and Galphat. PNAS 96 14383-14388.

Liu T, DeCostanzo AJ, Liu X, Wang H, Hallagan S, Moon RT \& Malbon CC $2001 \mathrm{G}$ protein signaling from activated rat frizzled-1 to the $\beta$-catenin-Lef-Tcf pathway. Science 292 1718-1722.

Malbon CC $2005 \beta$-Catenin, cancer, and G proteins: not just for frizzleds anymore. Science's STKE 2005 pe35.

Maya-Nunez G \& Conn PM 2001 Cyclic adenosine $3^{\prime}, 5^{\prime}$-monophosphate (cAMP) and cAMP responsive element-binding protein are involved in the transcriptional regulation of gonadotropinreleasing hormone $(\mathrm{GnRH})$ receptor by $\mathrm{GnRH}$ and mitogenactivated protein kinase signal transduction pathway in GGH(3) cells. Biology of Reproduction 65 561-567.

McManus EJ, Sakamoto K, Armit LJ, Ronaldson L, Shpiro N, Marquez R \& Alessi DR 2005 Role that phosphorylation of GSK3 plays in insulin and Wnt signalling defined by knockin analysis. EMBO Journal 24 1571-1583.

Millar RP, Lu ZL, Pawson AJ, Flanagan CA, Morgan K \& Maudsley SR 2004 Gonadotropin-releasing hormone receptors. Endocrine Reviews 25 235-275.

Millar RP, Pawson AJ, Morgan K, Rissman EF \& Lu ZL 2008 Diversity of actions of GnRHs mediated by ligand-induced selective signaling. Frontiers in Neuroendocrinology 29 17-35.

Mizusaki H, Kawabe K, Mukai T, Ariyoshi E, Kasahara M, Yoshioka H, Swain A \& Morohashi K 2003 Dax-1 (dosagesensitive sex reversal-adrenal hypoplasia congenita critical region on the $\mathrm{X}$ chromosome, gene 1) gene transcription is regulated by wnt 4 in the female developing gonad. Molecular Endocrinology 17 507-519.

Moon RT, Kohn AD, De Ferrari GV \& Kaykas A 2004 WNT and $\beta$-catenin signalling: diseases and therapies. Nature Reviews. Genetics 5 691-701.

Mulholland DJ, Dedhar S, Coetzee GA \& Nelson CC 2005 Interaction of nuclear receptors with the Wnt/ $\beta$-catenin/Tcf signaling axis: Wnt you like to know? Endocrine Reviews 26 898-915.

Naor Z 1997 GnRH receptor signaling: cross-talk of $\mathrm{Ca}^{2+}$ and protein kinase C. European Journal of Endocrinology 136 123-127.

Naor Z 2009 Signaling by G-protein-coupled receptor (GPCR): studies on the GnRH receptor. Frontiers in Neuroendocrinology 30 $10-29$.
Naor Z, Benard O \& Seger R 2000 Activation of MAPK cascades by G-protein-coupled receptors: the case of gonadotropin-releasing hormone receptor. Trends in Endocrinology and Metabolism 11 91-99.

Nateri AS, Spencer-Dene B \& Behrens A 2005 Interaction of phosphorylated c-Jun with TCF4 regulates intestinal cancer development. Nature 437 281-285.

Nelson WJ \& Nusse R 2004 Convergence of Wnt, $\beta$-catenin, and cadherin pathways. Science 303 1483-1487.

Ng SS, Mahmoudi T, Danenberg E, Bejaoui I, de Lau W, Korswagen HC, Schutte M \& Clevers H 2009 Phosphatidylinositol 3-kinase (PI3K) signaling does not activate the Wnt cascade. Journal of Biological Chemistry 284 35308-35313.

Parakh TN, Hernandez JA, Grammer JC, Weck J, Hunzicker-Dunn M, Zeleznik AJ \& Nilson JH 2006 Follicle-stimulating hormone/cAMP regulation of aromatase gene expression requires $\beta$-catenin. PNAS 103 12435-12440.

Pawson AJ \& McNeilly AS 2005 The pituitary effects of GnRH. Animal Reproduction Science 88 75-94.

Polakis P $2000 \mathrm{Wnt}$ signaling and cancer. Genes and Development 14 1837-1851.

Robinson DR, Zylstra CR \& Williams BO 2008 Wnt signaling and prostate cancer. Current Drug Targets 9 571-580.

Salisbury TB, Binder AK, Grammer JC \& Nilson JH 2007 Maximal activity of the luteinizing hormone $\beta$-subunit gene requires $\beta$-catenin. Molecular Endocrinology 21 963-971.

Salisbury TB, Binder AK \& Nilson JH 2008 Welcoming $\beta$-catenin to the gonadotropin-releasing hormone transcriptional network in gonadotropes. Molecular Endocrinology 22 1295-1303.

Salisbury TB, Binder AK, Grammer JC \& Nilson JH 2009 GnRHregulated expression of Jun and JUN target genes in gonadotropes requires a functional interaction between TCF/LEF family members and $\beta$-catenin. Molecular Endocrinology 23 402-411.

Schulte G \& Bryja V 2007 The Frizzled family of unconventional G-protein-coupled receptors. Trends in Pharmacological Sciences 28 518-525.

Shah S, Pishvaian MJ, Easwaran V, Brown PH \& Byers SW 2002 The role of cadherin, $\beta$-catenin, and AP-1 in retinoid-regulated carcinoma cell differentiation and proliferation. Journal of Biological Chemistry 277 25313-25322.

Spady TJ, Shayya R, Thackray VG, Ehrensberger L, Bailey JS \& Mellon PL 2004 Androgen regulates follicle-stimulating hormone $\beta$ gene expression in an activin-dependent manner in immortalized gonadotropes. Molecular Endocrinology 18 925-940.

Stambolic V \& Woodgett JR 1994 Mitogen inactivation of glycogen synthase kinase- $3 \beta$ in intact cells via serine 9 phosphorylation. Biochemical Journal 303 701-704.

Stavrou E, Millar RP \& Pawson AJ 2009 GnRH regulation of FoxO transcription factors. Society for Endocrinology BES 2009, Harrogate, UK. Endocrine Abstracts 19 P110.

Terry S, Yang X, Chen MW, Vacherot F \& Buttyan R 2006 Multifaceted interaction between the androgen and Wnt signaling pathways and the implication for prostate cancer. Journal of Cellular Biochemistry 99 402-410.

Thackray VG \& Mellon PL 2008 Synergistic induction of folliclestimulating hormone $\beta$-subunit gene expression by gonadal steroid hormone receptors and Smad proteins. Endocrinology 149 1091-1102.

Thackray VG, McGillivray SM \& Mellon PL 2006 Androgens, progestins, and glucocorticoids induce follicle-stimulating hormone $\beta$-subunit gene expression at the level of the gonadotrope. Molecular Endocrinology 20 2062-2079.

Thomas GM, Frame S, Goedert M, Nathke I, Polakis P \& Cohen P 1999 A GSK3-binding peptide from FRAT1 selectively inhibits the GSK3-catalysed phosphorylation of axin and $\beta$-catenin. FEBS Letters 458 247-251. 
Veeman MT, Axelrod JD \& Moon RT 2003 A second canon. Functions and mechanisms of $\beta$-catenin-independent Wnt signaling. Developmental Cell 5 367-377.

Yan W \& Tai HH 2006 Glycogen synthase kinase-3 phosphorylation, T-cell factor signaling activation, and cell morphology change following stimulation of thromboxane receptor $\alpha$. Journal of Pharmacological and Experimental Therapeutics 317 267-274.
Yang M, Zhong WW, Srivastava N, Slavin A, Yang J, Hoey T \& An S 2005 $\mathrm{G}$ protein-coupled lysophosphatidic acid receptors stimulate proliferation of colon cancer cells through the $\beta$-catenin pathway. PNAS 102 6027-6032.

Received in final form 26 January 2010

Accepted 3 February 2010

Made available online as an Accepted Preprint 4 February 2010 